\title{
Association between vasoactive peptide urotensin II in plasma and cerebral vasospasm after aneurysmal subarachnoid hemorrhage: a potential therapeutic target
}

\author{
*Thomas Clavier, MD, ${ }^{1-3}$ Alexandre Mutel, ${ }^{1,2}$ Laurence Desrues, $\mathrm{PhD},{ }^{1,2}$ \\ Antoine Lefevre-Scelles, MD, ${ }^{1-3}$ Gioia Gastaldi, MD, ${ }^{3}$ Mohamad El Amki, PhD, ${ }^{1,2}$ \\ Martine Dubois, PhD, ${ }^{1,2}$ Anthony Melot, MD, ${ }^{1,2,4}$ Véronique Wurtz, MD, ${ }^{1-3}$ Sophie Curey, MD, ${ }^{4}$ \\ Emmanuel Gérardin, MD, PhD, ${ }^{1,2,5}$ François Proust, MD, PhD, ${ }^{1,2,4}$ Vincent Compère, MD, PhD,1-3 and \\ Hélène Castel, $\mathrm{PhD}^{1,2}$
}

\begin{abstract}
${ }^{1}$ Normandie Université, UNIROUEN, INSERM, DC2N; ${ }^{2}$ Institute for Research and Innovation in Biomedicine; and Departments of ${ }^{3}$ Anesthesiology and Critical Care, ${ }^{4}$ Neurosurgery, and ${ }^{5}$ Radiology, Rouen University Hospital, Rouen, France
\end{abstract}

\begin{abstract}
OBJECTIVE Cerebral vasospasm (VS) is a severe complication of aneurysmal subarachnoid hemorrhage (SAH). Urotensin II (UII) is a potent vasoactive peptide activating the urotensin (UT) receptor, potentially involved in brain vascular pathologies. The authors hypothesized that UII/UT system antagonism with the UT receptor antagonist/biased ligand urantide may be associated with post-SAH VS. The objectives of this study were 2-fold: 1) to leverage an experimental mouse model of SAH with VS in order to study the effect of urotensinergic system antagonism on neurological outcome, and 2) to investigate the association between plasma UII level and symptomatic VS after SAH in human patients.
\end{abstract}

METHODS A mouse model of SAH was used to study the impacts of UII and the UT receptor antagonist/biased ligand urantide on VS and neurological outcome. Then a clinical study was conducted in the setting of a neurosurgical intensive care unit. Plasma UII levels were measured in SAH patients daily for 9 days, starting on the 1st day of hospitalization, and were compared with plasma UII levels in healthy volunteers.

RESULTS In the mouse model, urantide prevented VS as well as SAH-related fine motor coordination impairment. Seventeen patients with SAH and external ventricular drainage were included in the clinical study. The median plasma UII level was $43 \mathrm{pg} / \mathrm{ml}$ (IQR $14-80 \mathrm{pg} / \mathrm{ml})$. There was no significant variation in the daily median plasma UII level (median value for the 17 patients) from day 0 to day 8 . The median level of plasma UII during the 9 first days post-SAH was higher in patients with symptomatic VS than in patients without VS $(77 \mathrm{pg} / \mathrm{ml}$ [IQR $33.5-111.5 \mathrm{pg} / \mathrm{ml}] \mathrm{vs} 37 \mathrm{pg} / \mathrm{ml}$ [IQR $21-46 \mathrm{pg} / \mathrm{ml}], \mathrm{p}<0.05$ ). Concerning daily measures of plasma UII levels in VS, non-VS patients, and healthy volunteers, we found a significant difference between SAH patients with VS (median $66 \mathrm{pg} / \mathrm{ml}[\mathrm{IQR} 30-110 \mathrm{pg} / \mathrm{ml}]$ ) and SAH patients without VS (27 pg/ml [IQR 15-46 pg/ml], $\mathrm{p}<0.001)$ but no significant difference between VS patients and healthy volunteers (44 pg/ml [IQR 27-51 pg/ml]) or between non-VS patients and healthy volunteers.

CONCLUSIONS The results of this study suggest that UT receptor antagonism with urantide prevents VS and improves neurological outcome after SAH in mice and that an increase in plasma Ull is associated with cerebral VS subsequent to SAH in humans. The causality link between circulating UII and VS after SAH remains to be established, but according to our data the UT receptor is a potential therapeutic target in SAH.

https://thejns.org/doi/abs/10.3171/2018.4.JNS172313

KEYWORDS urotensin II; subarachnoid hemorrhage; cerebral vasospasm; human; intensive care unit; mouse; vascular disorders

\footnotetext{
ABBREVIATIONS $A C A=$ anterior cerebral artery; $A U C=$ area under the curve; $C S F=$ cerebrospinal fluid $\mathrm{DCl}=$ delayed cerebral ischemia; $E V D=$ external ventricular drainage; ICU = intensive care unit; IQR = interquartile range; IRB = institutional review board; $M C A=$ middle cerebral artery; $m R S=$ modified Rankin $S c a l e ; R O C=$ receiver operating characteristic; SAH = subarachnoid hemorrhage; SAPS II = Simplified Acute Physiology Score II; SE = standard error; UII = urotensin II; UT = urotensin (receptor); VS = vasospasm; WFNS $=$ World Federation of Neurosurgical Societies.
}

SUBMITTED September 15, 2017. ACCEPTED April 23, 2018.

INCLUDE WHEN CITING Published online October 19, 2018; DOI: 10.3171/2018.4.JNS172313.

*V.C. and H.C. share senior authorship of this work. 
$\mathrm{S}$ TROKE is the second leading cause of death worldwide, and death due to subarachnoid hemorrhage (SAH) represents about $30 \%$ of the total stroke-related mortality. ${ }^{14,17}$ Cerebral vasospasm (VS) is a frequent complication of aneurysmal SAH and is often associated with delayed cerebral ischemia. ${ }^{11,34} \mathrm{SAH}$ patients commonly experience sequelae, including motor and/or cognitive deficits, that affect their day-to-day functioning and quality of life. ${ }^{24} \mathrm{VS}$ been reported to occur in 50\%-70\% of cases between 4 and 21 days after aneurysmal rupture and can persist for up to 4 weeks, but its pathophysiology is complex and not fully understood. ${ }^{26,28}$ Currently, treatments are mainly symptomatic and rely on calcium channel antagonists, euvolemia, targeted hypertension, and in some cases, endovascular therapy (transluminal angioplasty, intraarterial vasodilators). ${ }^{10,18}$ Biomarkers have been proposed for prediction or early diagnosis of SAH-associated VS; of these biomarkers, copeptin and cellular microparticles in plasma and neuropeptide $\mathrm{Y}$ in cerebrospinal fluid (CSF) have been the most studied in humans. ${ }^{15,19,20,29,30}$ Among vasoconstrictive peptides, the level of endothelin-1 (ET-1) in plasma can be considered as an early marker of VS, but a specific ET-1 receptor antagonist did not improve mortality or functional clinical outcome. ${ }^{4,23}$

Urotensin II (UII), a potent vasoactive peptide, represents a new potential marker of brain vascular pathology. Human UII (hUII) and UII-related peptide (URP) possess a common highly conserved cyclic biologically active sequence and are endogenous ligands of the $\mathrm{G}$ protein-coupled receptor, referred to as the UT (urotensin) receptor (or simply as UT). ${ }^{3,31}$ The level of UII in plasma often varies during vascular pathologies, such as endothelium dysfunction, arterial blood pressure elevation, and/ or vasoconstriction. ${ }^{1,13}$ In addition, UII induces proinflammatory activity in human endothelial cells, ${ }^{8,24}$ astrocyte proliferation, ${ }^{6,17}$ cerebral vasoconstrictor effects, ${ }^{27}$ and brain damage during ischemic insult. ${ }^{7}$ Thus, through its vasoconstrictive action and its neuroinflammatory effects, UII could play a role during cerebral VS. We postulated that UII, in the blood and/or secreted in the subarachnoid space during the SAH, would activate UT expressed in the cerebral arterial network, participating in the symptomatic VS and potentially affecting clinical outcome, and that UII levels in plasma would be associated with the occurrence of VS.

The primary objective of this study was to determine if UII/UT system antagonism with urantide improves VS and neurological outcome in a mouse model of SAH. Secondary objectives were: 1) in the mouse, to establish UII/ UT expression in cerebral main arteries after SAH, the effect of SAH, and to study the kinetics of UII variation in plasma after SAH; and 2) in humans, to assess the association between the UII level in plasma and in CSF and symptomatic VS; to assess the association between the UII level in plasma and CSF, blood pressure, SAPS II, age, and duration of intensive care unit (ICU) hospitalization; to compare UII levels in plasma between patients with SAH and healthy volunteers; and to study the temporal variation of UII levels in plasma and CSF in SAH patients during the first days of ICU hospitalization.

\section{Methods}

In an experimental mouse model of SAH, we first validated the urotensinergic system as a potential therapeutic target. Then, because of the absence of previously published data on the potential association between UII and VS in SAH, the present adapted assay (choice of antibody to detect UII-like peptides), and the variable levels of UII in plasma depending on the study or the patient, we performed a pilot study in human patients to determine the optimum method to measure UII in plasma as a possible biomarker to predict the occurrence of symptomatic VS after aneurysmal SAH in humans. In both the mouse model and human patients, we investigated the effects of UII/UT system antagonism with urantide on VS and neurological outcome after SAH.

\section{Animal Study \\ Animal Care}

Male C57Bl/6 J Rj mice (Janvier) aged 8-12 weeks were housed under controlled standard environmental conditions: $22^{\circ} \mathrm{C} \pm 1{ }^{\circ} \mathrm{C}, 12$ hours/12 hours light/dark cycle, and water and food available ad libitum. All procedures were performed under the supervision of $\mathrm{H}$. Castel in accordance with the French Ethical Committee and guidelines of European Parliament Directive 2010/63/EU and the Council for the Protection of Animals Used for Scientific Purposes. This project was approved by the local ethics committee.

\section{SAH Mouse Model Procedure}

This model of SAH was performed through intracisternal injection of arterial blood into the magna cisterna of the mice in the SAH animal groups as previously described. ${ }^{12,22}$ Briefly, mice were anesthetized with isoflurane (5\% induction and $2 \%$ maintenance) and the transparent atlanto-occipital membrane was exposed and a pulled hematological glass micropipette (GC150F-15; Harvard Apparatus) was introduced into the cisterna magna. A C57Bl/6 J Rj mouse (age 12 weeks) was used as a donor for arterial blood, which was obtained via intracarotid puncture. Freshly drawn blood $(60 \mu \mathrm{l})$ was injected into the cisterna magna over a period of 1 minute. Shamoperated mice underwent the same procedure but received $60 \mu \mathrm{l}$ of normal saline $(\mathrm{NaCl} 0.9 \%)$. After surgery, mice were placed into their home cage and fed with mashed lab chow. Postoperative analgesia was ensured, according to the protocols of the National Cancer Institute (Frederick, Maryland), by ropivacaine hydrochloride $(2 \mathrm{mg} / \mathrm{ml})$ at the site of blood injection and under the skin and paracetamol administered orally in drinking water $(1.6 \mathrm{mg} / \mathrm{ml})$ for 48 hours.

To evaluate the impact of the direct effect of human UII and the antagonist/biased ligand of UT receptor urantide, we administered UII (PolyPeptide Laboratories) or urantide (Phoenix Pharmaceuticals) at day 0 (D0) into the cisterna magna ( $2 \mu \mathrm{g} / \mathrm{kg}$ in $50 \mu \mathrm{l}$ of UII or $2 \mu \mathrm{g} / \mathrm{kg}$ in $50 \mu \mathrm{l}$ of urantide) in animals that had undergone blood injection as well as animals that had undergone the Sham procedure ( $\mathrm{NaCl} 0.9 \%$ injection). Control animals received $50 \mu \mathrm{l}$ of $\mathrm{NaCl} 0.9 \%$. On D2 (48 hours post-SAH), an intravenous 
tail injection of $50 \mu \mathrm{l}$ of UII, urantide, or $\mathrm{NaCl}$ was carried out under brief inhaled anesthesia (isoflurane).

The number of animals used in the different series of experiments is provided in Supplementary Table S1.

\section{Radioimmunoassay of UII in Mouse Plasma}

At D1 and D10 postsurgery, blood samples were transcardially taken at the time of euthanization of Sham and $\mathrm{SAH}$ mice. The samples were centrifuged at $3000 \mathrm{~g}$ for 15 minutes and plasma was frozen at $-20^{\circ} \mathrm{C}$ before analysis. The concentration of UII in mouse plasma was also determined by radioimmunoassay using a commercial kit purchased from Phoenix Pharmaceuticals, Inc. (RK-07108). The assay was performed according to the commercial instructions.

\section{Cerebral Vasospasm and Immunohistochemistry}

Immunohistochemistry procedures to study cerebral VS and animal behaviors are described in the Supplementary Information. Briefly, the animals were deeply anesthetized and decapitated, and the brains were removed and postfixed with paraformaldehyde 4\% (PFA).

Frozen brains were serially sectioned using a cryomicrotome (CM 3050S, Leica, PRIMACEN platform) into $20-\mu \mathrm{m}$ transverse slices. Slice collection began at the anterior part of the prefrontal cortex (bregma +3.2 ) and extended rostrocaudally to the posterior cerebellum, using previously coated glass slides (gelatin $0.5 \%$ and alum chrome 5\% in distilled water) according to a stereotaxic brain atlas. For VS identification (H \& E staining) or microscopic fluorescence imaging procedures, see Supplementary Information.

\section{Behavioral Experimental Procedures}

Activity of mice was evaluated as previously described..$^{12}$ The distance crossed and the number of times the animals reared up on their hind legs were recorded during a test of 5 minutes' duration. Behaviors were recorded with the videotracking software ANY-maze (Stoelting). Muscular strength, dynamic equilibrium (beam walking test), or locomotion was investigated in selected groups of mice (see Supplementary Information).

\section{Human Study \\ Patient Population}

This prospective observational study was conducted at the Rouen University Hospital in accordance with the Declaration of Helsinki and its later amendments. It was approved by the hospital's institutional review board (IRB). Written consent was systematically obtained. This paper adheres to the applicable EQUATOR (Enhancing the QUAlity and Transparency Of health Research) guidelines.

Patients admitted to the neurosurgical intensive care unit (ICU) with SAH from aneurysmal origin and external ventricular drainage (EVD) were included. Exclusion criteria were age under 18 years, patient under guardianship, pregnancy, or patient refusal. Data collection included demographic characteristics, aneurysm localization, sur- vival, Fisher and World Federation of Neurosurgical Societies (WFNS) grades, Simplified Acute Physiology Score II (SAPS II), daily mean systolic arterial blood pressure, duration of hospitalization, and neurological outcome on the 10th day (D10) and 6th month (M6) after SAH. Neurological outcome was assessed with the modified Rankin Scale (mRS) and dichotomized as favorable (mRS score 0-3) or unfavorable (mRS score 4-6). The occurrence of a delayed cerebral ischemia (DCI) diagnosed on the basis of neurological symptoms (aphasia, hemiparesis or hemiplegia, disorders of consciousness) associated with a proven VS on neuroradiology explorations (angiography and/ or tomodensitometry [TDM] angiography) was also recorded. The assessment of VS was performed by a senior neuroradiologist (E.G.) with long experience, according to the following criteria: decrease in caliber of cerebral arteries (from D2 to D15) in comparison with previous reference neuroradiology exploration of cerebral arteries (D0 or D1), rosary bead-like appearance, and left/right asymmetry of artery caliber. Radiological assessments were performed blinded to the neurological condition of the patient. The diagnosis was retained after exclusion of other confounding causes (hematoma, rebleeding, meningitis, or abscess). Patients with DCI without VS were not included in the VS group, and the diagnosis of VS was only based on the arterial caliber neuroradiological conclusions. In this pilot study, the occurrence of VS was monitored from D0 to D15.

In order to compare the UII-like peptide levels in plasma in SAH patients to levels in individuals without SAH, volunteers with no evidence of severe acute or chronic concomitant disease and not following any regular medication regimen were included, with the support of our local clinical investigation center. Single venous blood samples were collected between 8:00 and 9:00 AM under the IRB-approved study protocol. Written consent was systematically obtained.

\section{Sample Collection and UII-Like Radioimmunoassay.}

Collection of samples from the SAH patients during hospitalization was scheduled for 8:00-9:00 AM, consistent with a circadian rhythm potentially influencing the release of UII. Each patient who had an external ventricular drain in place had daily plasma and CSF sampling during a total period of 9 days following ICU admission (from D0 to D8). The duration of daily blood or CSF samplings (9 days) was chosen because of the time points usually described concerning the occurrence of VS after the SAH event. ${ }^{10,11}$ Blood was centrifuged at $2000 \mathrm{~g}$ (10 minutes) at $4^{\circ} \mathrm{C}$ and samples were stored at $-80^{\circ} \mathrm{C}$ until radioimmunoassay. CSF was taken from EVD and immediately stored at $-80^{\circ} \mathrm{C}$ until radioimmunoassay. Blood and CSF samplings were stopped after ICU discharge and/or EVD ablation.

Calibration curves for the assessment of UII in plasma of patients and volunteers and procedures of UII-like radioimmunoassay in plasma and CSF are detailed in the Supplementary Information.

\section{Statistical Analysis}

In the text, values are presented as mean and stand- 
ard error (SE) or median with interquartile range (IQR; 25 th to 75 th percentile). For figures, values and intervals used are specified in the legends. The significance level was 0.05 for all tests performed. Statistics were calculated using GraphPad Prism software.

\section{Statistical Analysis of Animal Data}

Data were analyzed with parametric tests unless a normal distribution and variance homogeneity were not present. In such instances, nonparametric analyses were performed (for example, see Fig. 2) by using Kruskal-Wallis ANOVA followed by Dunn's multiple comparison test.

\section{Statistical Analysis of Human Data}

The number of patients and the standard deviation of our data gave a power of $80 \%$ to detect a doubling of UII levels in plasma of patients with a VS (2-sided test; alpha risk $=0.05$ ).

We first analyzed variations of UII levels in plasma and CSF in SAH patients with Friedman's test (for testing the difference between several related samples: multiple comparisons of UII in plasma and CSF from D0 to D8 in patients with or without VS). Then, the group of patients with symptomatic VS was compared to the group of SAH patients without VS by means of Mann-Whitney (UII plasma/CSF levels) and Fisher's exact (neurological outcome) tests. Afterward, associations between UII level in plasma/CSF and blood pressure, SAPS II, age, and duration of ICU hospitalization were tested using Spearman's rank correlation coefficient $\left(\mathrm{r}_{\mathrm{s}}\right)$. Comparisons of daily UII levels in SAH patients with VS, SAH patients without VS, and healthy volunteers were made using the KruskalWallis test with a Dunn's posttest as these 3 groups were not related to each other. Receiver operating characteristic (ROC) curve analysis, including area under the ROC curve (AUC), was used to determine a threshold level of UII that would enable differentiation of groups with and without VS.

\section{Results}

\section{Animal Study}

In our model, the mortality rates for the SAH groups were $35.9 \%$ and $30.7 \%$ for $\mathrm{SAH}-\mathrm{NaCl}$ and $\mathrm{SAH}$-urantide mice, respectively, whereas in the Sham groups, the mortality rates were only $8.8 \%$ and $7.9 \%$ for Sham- $\mathrm{NaCl}$ and Sham-urantide mice, respectively, occurring during surgery or the first 24 hours following SAH. This model displayed evidence of VS in the MCA at both D2 and D7 (Fig. 1A). In the Sham and SAH mice, brain arteries expressed UT receptor (Fig. 1B), whereas UII was observed in the MCA only in the SAH mice (Fig. 1B), indicating expression of both UII and UT receptor in vasospasmed brain arteries during SAH. To assess whether the urotensinergic system is involved in a macroscopic VS within a cerebral brain artery after blood diffusion in the subarachnoid space, we calculated the luminal area/wall area ratio from $\mathrm{H} \& \mathrm{E}$-stained brain slices obtained at D7 post-SAH from animals in the Sham, Sham-UII, SAH, SAH-UII, and SAH-urantide groups (Fig. 1C). SAH induced by a single injection of blood in the cisterna magna induced VS of the large anterior cerebral artery (ACA) and middle cerebral artery (MCA), highlighted by a significant decrease of the lumen/wall area ratio compared with the ratio in Sham-operated mice (ACA: mean $[ \pm \mathrm{SE}] 0.17 \pm 0.023$ in the $\mathrm{SAH}$ group vs $0.32 \pm 0.026$ in the Sham- $\mathrm{NaCl}$ group, $\mathrm{p}=0.0004$; MCA: $0.23 \pm 0.013$ in the SAH group vs 0.32 \pm 0.025 in the Sham- $\mathrm{NaCl}$ group, $\mathrm{p}=0.02$ ). Interestingly, there was no statistically significant difference between Sham-operated mice and urantide-treated SAH mice with respect to the ACA or MCA, and significance was reached when comparing MCA in SAH mice and mice in the SAH-urantide group $(0.23 \pm 0.013$ vs $0.33 \pm 0.03$, respectively; $p=0.02$ ), suggesting that urantide probably prevents the VS associated with SAH at D7. Note that although a slight tendency was observed when UII was added, no additional effect of UII on VS of these arteries was detected (Fig. 1C). Detectable levels of UII were found in plasma by radioimmunoassay at D1 and D10 post-SAH and did not show any significant difference between Sham and SAH animals (Fig. 1D).

To investigate the long-term impact of SAH on sensorimotor function, behavioral tests were carried out on Sham and SAH mice. To specifically explore a potential role of the UT receptor, the aggravating role of UII or the preventive role of the UT antagonist/biased ligand urantide was also challenged (Fig. 2). The weight gain of $\mathrm{SAH}-\mathrm{NaCl}$ mice was significantly reduced from D2 to D10 compared with that of control mice and at D2 and D8 compared with that of Sham- $\mathrm{NaCl}$ mice (KruskalWallis and Dunn's multiple comparison test; Fig. 2A). The spontaneous activity of the mice was not significantly affected by SAH as evaluated by distance crossed (Fig. 2B) and number of times the animals reared (data not shown). Urantide administration did not significantly affect this activity (Fig. 2B). No significant difference in muscle strength, static equilibrium, or motor coordination was observed between Sham and SAH, in the absence or the presence of urantide (Fig. 2C-E). However, in the beam walking test, the slip frequency of $\mathrm{SAH}-\mathrm{NaCl}$ animals was significantly increased compared with that of Sham-NaCl mice $(p=0.004)$ at $D 7$, indicating a selective sensorimotor deficit induced by the hemorrhage. The SAH mice that received urantide showed significantly better performance than SAH-NaCl mice (Kruskal-Wallis, Dunn's posttest, $\mathrm{p}$ $=0.04 ;$ Fig. $2 \mathrm{~F}$ ). Mice receiving UII in the injected blood did not show a significant difference in the number of slips per minute compared with SAH-NaCl mice (Fig. 2F).

\section{Human Study}

In 17 patients, 2 SAHs were linked to an aneurysm localized in the posterior cerebral circulation and 15 SAHs were secondary to a rupture of an aneurysm from the anterior cerebral circulation. The clinical and demographic characteristics of the patients are summarized in Table 1. The median levels of UII at D0 (the 1st day of hospitalization) were $43 \mathrm{pg} / \mathrm{ml}$ (IQR $14-80 \mathrm{pg} / \mathrm{ml}$ ) in plasma and 22 $\mathrm{fg} / \mathrm{ml}$ (IQR 5-68 fg/ml) in CSF. The values of UII levels in plasma and CSF for each day are summarized in Fig. $3 \mathrm{~A}$ and $\mathrm{B}$. There was no statistically significant variation of UII levels in plasma or CSF from D0 to D8. Moreover, we did not find any significant correlation between daily 
Clavier et al.
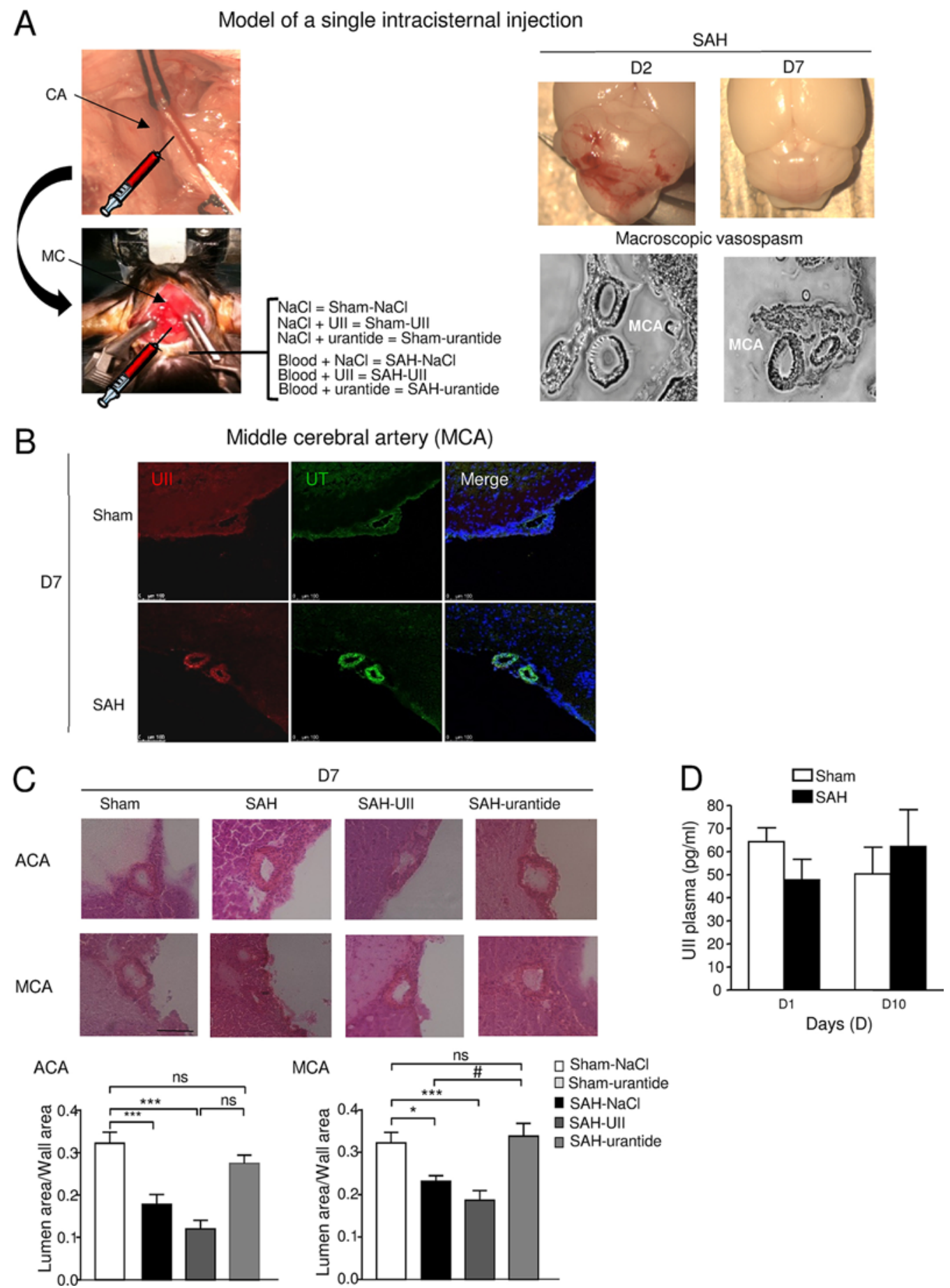

FIG. 1. The urotensinergic system in plasma and main cerebral arteries in the mouse model of SAH. A: Creation of SAH model by intracisternal injection of arterial blood. As shown in the images on the left, arterial blood is drawn by the carotid route from a C57BI/6 J mouse and immediately injected with a glass micropipette into the cisterna magna (MC) of another mouse to create the SAH model. The photographs on the upper right of this panel show direct visualization of the distribution of blood (D2 and D7) within the cerebellum after administration in the cisterna magna. The photomicrographs show the optical microscopic visualization of vascular parietal morphology suggestive of VS of the MCA at D2 and D7 ( $n=3 /$ group). CA = carotid artery. $B$ : Immunolabeling of UII (red) and UT (green) in MCA from Sham and SAH mouse brains 7 days after SAH. UT was found to be expressed in the MCA wall in the Sham and SAH mice, while UII was likely neo-expressed in the vascular wall of the MCA in the SAH mice. DAPI in blue. Scale bar $=100 \mu \mathrm{m}$. C: Vasospasm of large cerebral arteries after SAH, in the absence or the presence of Ull or urantide in the cisterna magna. Representative photomicrographs showing the morphology (lumen and wall thickness) of the ACA (bregma $+1.10 \mathrm{~mm}$ ) and the MCA (bregma - $1.22 \mathrm{~mm}$ ) in Sham and SAH-NaCl, SAH-UII, and SAH-urantide brain sections at D7. H \& E; scale bar $=50 \mu \mathrm{m}$. Quantification histograms of lumen area/wall area ratio showing significant VS in the ACA and MCA in SAH-NaCl mice compared with Sham-NaCl mice and significant VS prevention in SAH-urantide compared with SAH-NaCl mice. One-way ANOVA, Tukey's multiple comparison test ( ${ }^{*} p<0.05,{ }^{* * *} p<0.001, \# p<0.05$, ns = not significant). D: Schematic values of UII level in plasma following the occurrence of SAH in mice. Results are presented as mean with SEM ( $n=3$ to $5 /$ group). No significant variation of UII level in plasma at D1 and D10 between Sham and SAH (Kruskal-Wallis). Figure is available in color online only. 

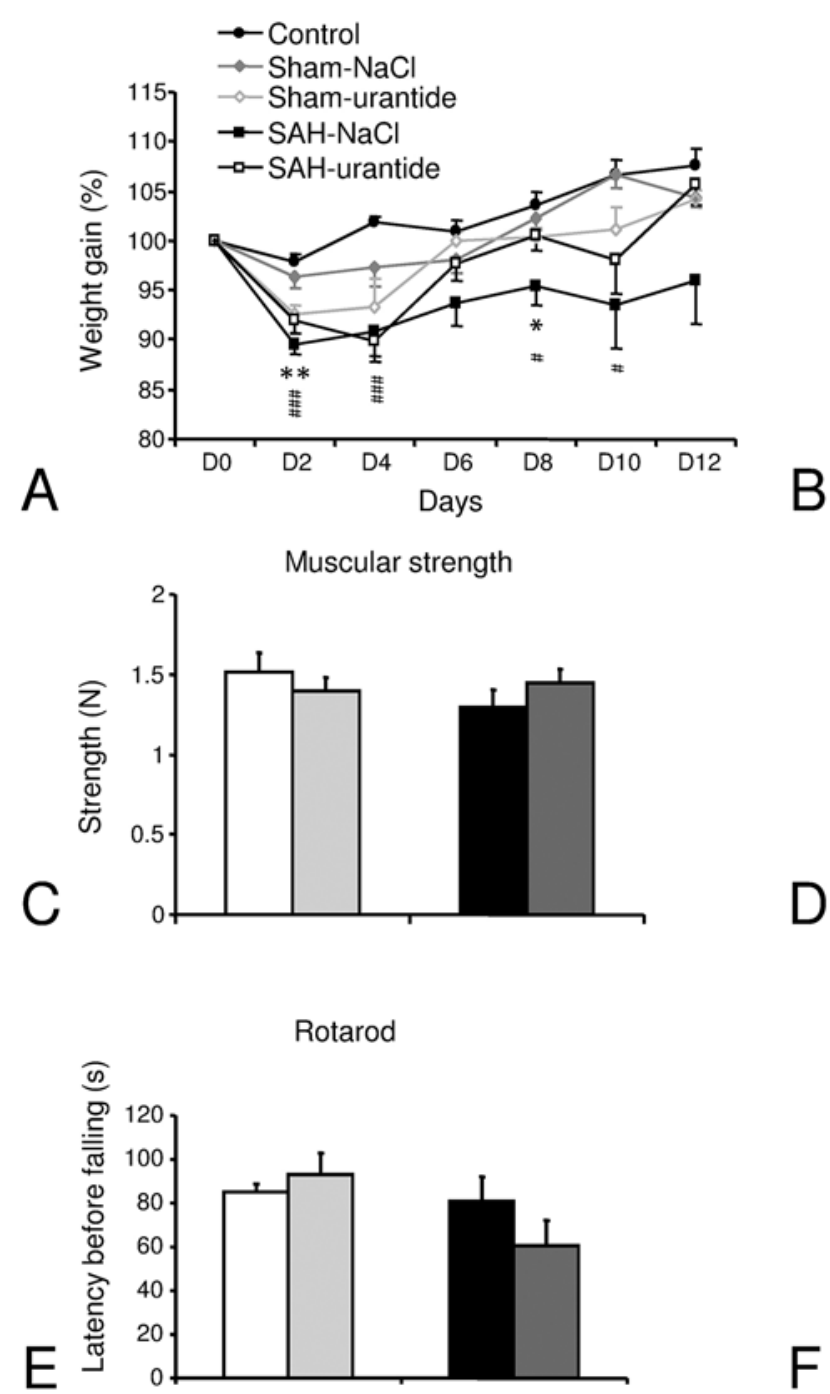

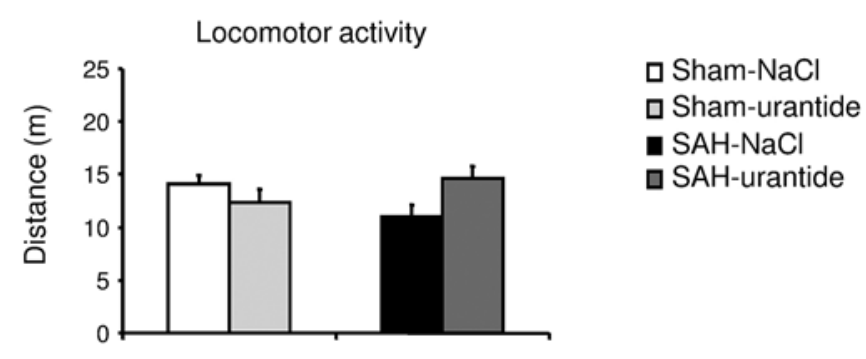

B

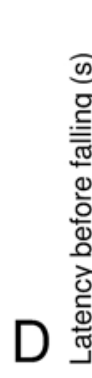

Unstable platform
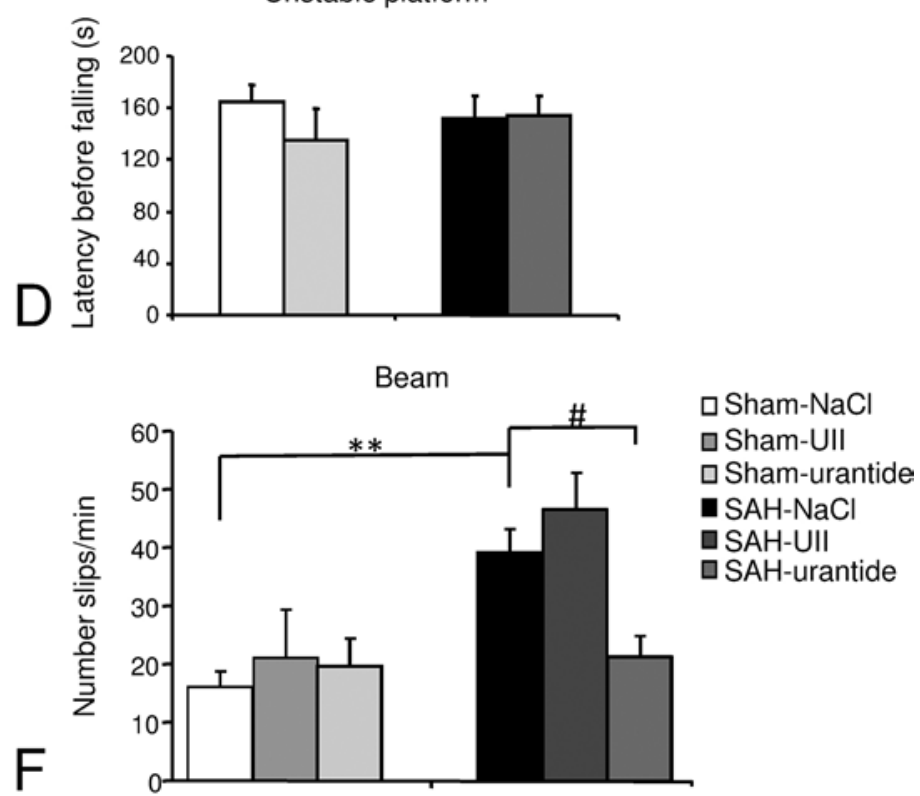

FIG. 2. Behavioral characterization of the SAH mouse model and the effect of the antagonist/biased ligand urantide. A: Weight gain of SAH mice in the presence or the absence of urantide from D0 to D12. SAH-NaCl mice displayed significantly reduced weight gain on days $2,4,6,8$, and 10 compared to control mice and on days 2 and 8 compared with Sham-NaCl mice. Weight gain of Sham- $\mathrm{NaCl}$ mice was reduced compared to that of control mice only on $\mathrm{D} 4$, and weight gain of Sham-urantide mice was reduced on D2 compared to Sham- $\mathrm{NaCl}$ mice (Kruskal-Wallis, Dunn's multiple comparison test; \#p < 0.05, \#\#\#p < 0.001, SAH$\mathrm{NaCl}$ vs control; ${ }^{*} p<0.05,{ }^{* *} p<0.01, \mathrm{SAH}-\mathrm{NaCl}$ vs Sham-NaCl; $n=5$ [at D12] to 31 [at D0]). B and C: Spontaneous activity and muscular strength in SAH mice and impact of urantide. Locomotion (B) and muscular strength (C) were not modified in SAH-NaCl compared with Sham- $\mathrm{NaCl}$ mice $(p>0.05)$. Urantide was associated with an increase of locomotor activity in SAH compared with $\mathrm{SAH}-\mathrm{NaCl}$ mice (Student t-test, ${ }^{*} \mathrm{p}<0.05, \mathrm{n}=6$ /group). $\mathrm{D}$ and E: Equilibrium, motor coordination, and impact of urantide treatment. SAH mice treated with $\mathrm{NaCl}$ or urantide did not show alteration of static equilibrium performances evaluated in the unstable platform test (D) and did not show deficits in motor coordination in the rotarod test (E) compared with Sham-NaCl or Shamurantide mice (Student t-test, 6/group). F: SAH-NaCl mice displayed selective impairment of dynamic equilibrium and fine motor coordination performance in the beam test compared with Sham-NaCl mice (Kruskal-Wallis, Dunn's multiple comparison test, ${ }^{* *} \mathrm{p}$ $<0.01,9-12$ /group). Urantide-treated SAH mice demonstrated improved performance in the beam test compared with $\mathrm{SAH}-\mathrm{NaCl}$ mice $(\# p<0.05, n=9-13)$. There was no significant effect of $\mathrm{UII}$ in the Sham- $\mathrm{NaCl}$ and $\mathrm{SAH}-\mathrm{NaCl}$ groups.

UII levels in plasma and those in CSF $\left(\mathrm{r}_{\mathrm{s}}=-0.08[95 \% \mathrm{CI}\right.$ -0.27 to 0.11$], \mathrm{p}=0.4)$.

Twenty-three healthy volunteers were also included in this study. There was no statistically significant difference between the volunteers and the patients with respect to age (median 38 years [IQR 29-58 years] vs 48 years [IQR $42-56$ years]) or sex ratio (M/F ratio 0.9 vs 1.1). Among the 17 patients included, 6 had VS during the first 10 days of hospitalization. Comparison of daily measures of UII levels in the plasma of VS patients, non-VS patients, and volun- teers showed a statistically significant difference between VS and non-VS patients (median $66 \mathrm{pg} / \mathrm{ml}$ [IQR 30-110 pg/ $\mathrm{ml}$ ] vs $27 \mathrm{pg} / \mathrm{ml}$ [IQR $15-46 \mathrm{pg} / \mathrm{ml}], \mathrm{p}<0.001)$. But no significant difference was observed between the VS group and the volunteers (median $66 \mathrm{pg} / \mathrm{ml}$ [IQR 30-110 pg/ml] vs 44 $\mathrm{pg} / \mathrm{ml}$ [IQR $27-51 \mathrm{pg} / \mathrm{ml}]$ ) or between the non-VS patient group and the volunteers (median $27 \mathrm{pg} / \mathrm{ml}$ [IQR 15-46 pg/ $\mathrm{ml}$ ] vs $44 \mathrm{pg} / \mathrm{ml}$ [IQR 27-51 pg/ml]; Fig. 3C).

The median level of UII in plasma during the 9 first days after SAH was significantly higher in patients with 
TABLE 1. Summary of clinical and demographic characteristics of the $17 \mathrm{SAH}$ patients included in the study

\begin{tabular}{lc}
\hline \multicolumn{1}{c}{ Characteristic } & Value \\
\hline Age in yrs & $48(41.5-56)$ \\
\hline Sex, $\mathrm{n}$ & 8 \\
\hline Male & 9 \\
\hline Female & $34(20-48)$ \\
\hline SAPS II & $4(3-4)$ \\
\hline Fisher grade & $3(2-4)$ \\
\hline WFNS grade & $10(2-23)$ \\
\hline Duration of mechanical ventilation in days & $27(19-60)$ \\
\hline Length of hospital stay in days
\end{tabular}

Values are median (IQR) unless otherwise indicated.

symptomatic VS than in patients without VS $(77 \mathrm{pg} / \mathrm{ml}$ [IQR 33.5-111.5 pg/ml] vs $37 \mathrm{pg} / \mathrm{ml}$ [IQR $21-46 \mathrm{pg} / \mathrm{ml}$, $\mathrm{p}=0.04$; Fig. $4 \mathrm{~A}$ ). No significant difference was found concerning the mean level of UII in CSF between patients with and without symptomatic VS (Fig. 4B). With respect to level of UII in plasma, the AUC allowing discrimination of patients with symptomatic VS from patients without symptomatic VS was $0.81(95 \% \mathrm{CI} 0.57-1, \mathrm{p}=0.04)$. With a cutoff value of $61.5 \mathrm{pg} / \mathrm{ml}$ of UII in plasma, the sensitivity was $66.7 \%(95 \%$ CI $22.3 \%-95.7 \%)$ and the specificity was $100 \%$ (95\% CI 71.5\%-100\%) (Fig. 4C). When comparing the VS and no-VS groups, there was a significant difference in the neurological outcome at D10, with a more favorable outcome in the no-VS group $(100 \%$ vs $0 \%, p=$ 0.02; Fig. 4D), whereas no difference was measured at M6 ( $82 \%$ vs $50 \%, p=0.12$; Fig. 4D). Individual $m R S$ scores of each patient are provided in Supplementary Table S2. The sole deceased patient of the cohort had symptomatic VS. In addition, a negative correlation was found between the SAPS II and UII level in plasma on D0 $\left(\mathrm{r}_{\mathrm{s}}=-0.57[95 \%\right.$ $\mathrm{CI}-0.84$ to -0.09$], p=0.02$; Fig. 4E), without correlation between CSF UII level at D0 and SAPS II $\left(\mathrm{r}_{\mathrm{s}}=-0.34[95 \%\right.$ $\mathrm{CI}-0.72$ to 0.21$], \mathrm{p}=0.2$; Fig. $4 \mathrm{~F}$ ). There was no correlation between daily UII levels in plasma and daily mean systolic blood pressure, age, duration of hospitalization, or duration of mechanical ventilation.

\section{Discussion}

Aneurysmal SAH is a common disease responsible for significant mortality and morbidity related to extremely debilitating neurological sequelae in survivors. ${ }^{2}$ After the
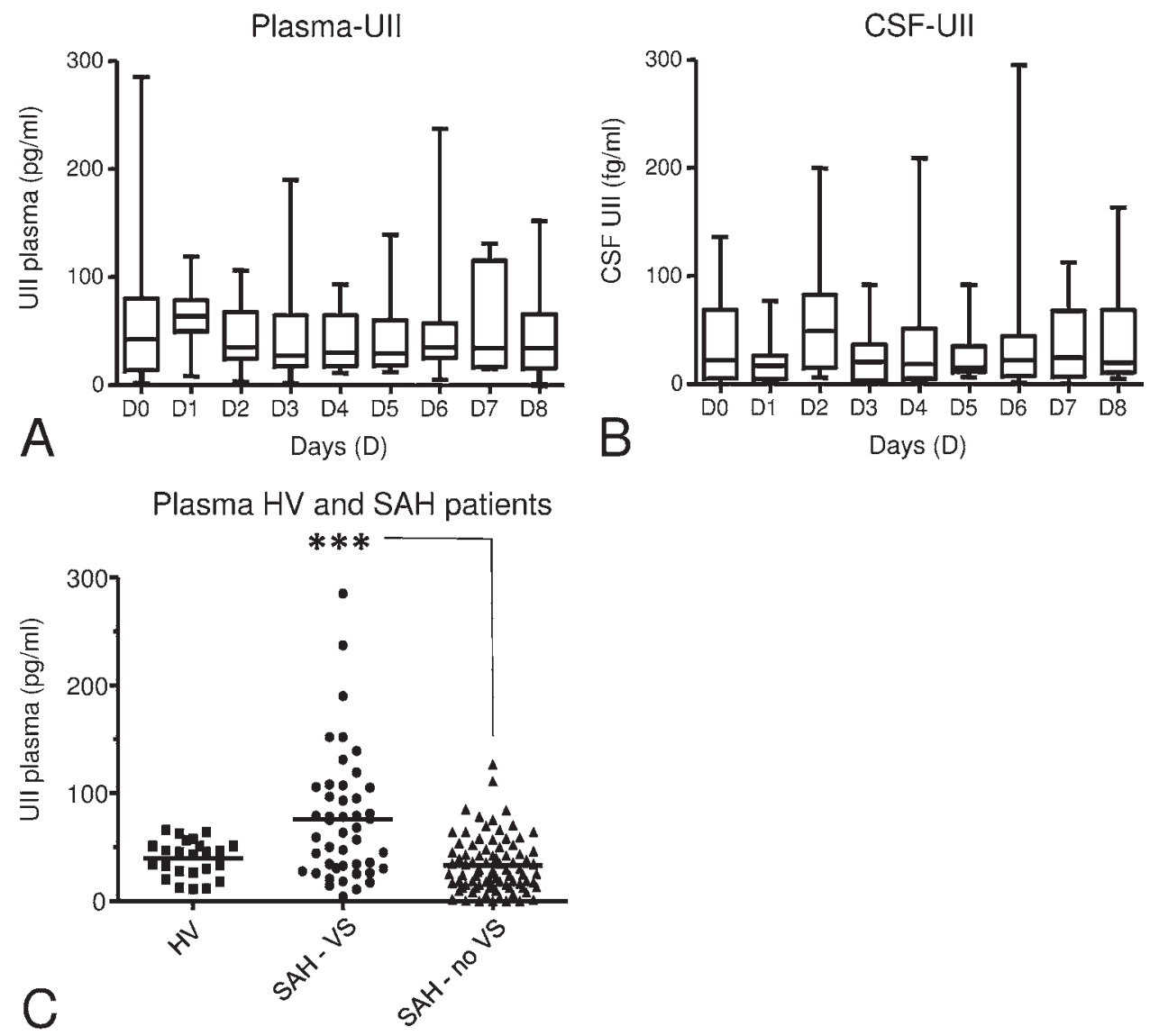

FIG. 3. Schematic values of UII in plasma and CSF during the 9 days following the occurrence of SAH. A and B: Box and whiskers plot showing the median values (horizontal lines) with IQRs (boxes) and extreme values (whiskers). There was no significant variation of UII levels in plasma or CSF from D0 to D8 (Kruskal-Wallis test). C: Daily measures of Ull levels in plasma in SAH patients with VS (SAH-VS), SAH patients without VS (SAH-no VS), and healthy volunteers (HV). The mean value for each group is indicated by a horizontal line. ${ }^{* *} p<0.001$ (VS vs no-VS group) (Kruskal-Wallis test). 

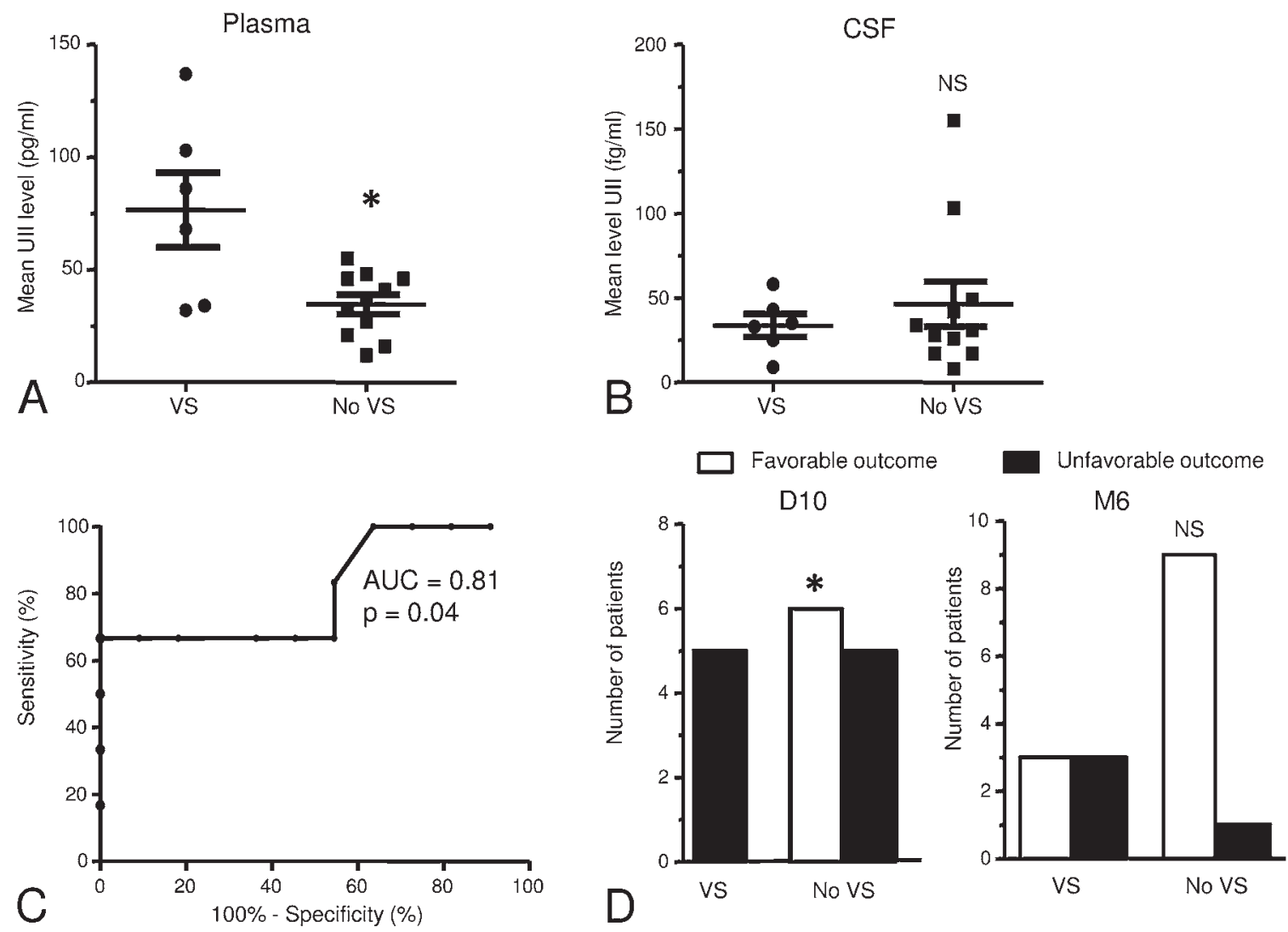

- UII levels in plasma at D0
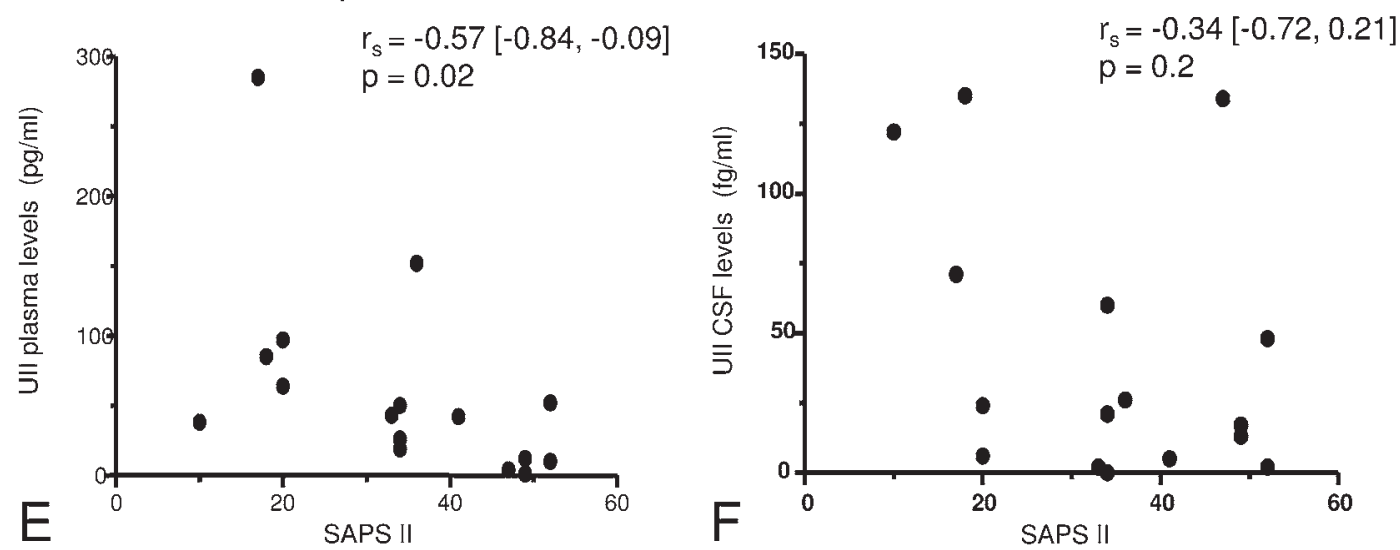

FIG. 4. Mean levels of UII in plasma (A) and CSF (B), ROC (C), and neurological outcome (D) following SAH in patients with and without symptomatic VS. A and B: Results are presented as mean with SEM for patients with (black circle) or without (black square) symptomatic VS. ${ }^{*} p<0.05$ (for comparison with VS group, Mann-Whitney test). NS = not significant. C: ROC curve generated with mean levels of UII in plasma in the VS and no-VS patient groups. The ROC curve is the plot of the true-positive rate (sensitivity) versus the false-positive rate (100\% - specificity) for different positivity thresholds (i.e., different cutoff levels of plasma UII). The calculated value of the AUC was 0.81 (superior to the random value of 0.5 ), indicating that the mean UII level in plasma discriminated patients with and without VS ( $p<0.05)$. D: Neurological outcome in the VS and no-VS groups at 10 days (D10) and 6 months (M6) post-SAH. Results are presented as absolute values. Neurological outcome was assessed with the mRS and dichotomized as favorable (mRS score 0-3) and unfavorable (mRS score 4-6). * $\mathrm{p}<0.05$ (1-tailed Fisher's exact test, comparison with VS group). E and F: Correlation between UII levels in plasma (E) and CSF (F) on the 1st day of hospitalization (D0) and SAPS II. Spearman's coefficients $\left(r_{s}\right)$ are shown with upper and lower bounds of $95 \%$ confidence intervals.

first part of our work, conducted in a preclinical mouse model, suggested a preventive effect of urotensinergic system inhibition on neurological deficits after VS, we explored the potential link between this peptide system and SAH in human patients.
In humans, VS is followed by complications including secondary brain ischemia, which likely leads to cognitive deficits in executive functions such as planning, attention, and decision making. ${ }^{2}$ Thus in our murine model of SAH, which is a relatively nonsevere model, there was an in- 
creased slip frequency in the beam walking test, suggesting that fine motor coordination and dynamic equilibrium are altered 7 days post-SAH. In accordance with these findings, beam walking deficits and spatial memory alteration were previously described in different rodent models of SAH. ${ }^{16,32}$ The urotensinergic system has been linked to numerous pathophysiological states, and previous studies have validated UT antagonists such as urantide. It exerts potent antagonism with no intrinsic activity in ex vivo models ${ }^{21,25}$ or biased activity in human embryonic kidney (HEK) cells expressing human UT receptor. ${ }^{5}$ We showed here that urantide, administered during the hemorrhage event, allowed a functional improvement of SAH-induced deficits in motor coordination and dynamic equilibrium. In contrast, when UII was co-applied with blood in the subarachnoid space, the SAH-sensorimotor defects were not exacerbated, suggesting that the urotensinergic system is likely to be widely recruited during SAH.

This finding opens the question of the involvement of the urotensinergic system in the VS pathophysiology often associated with neurological disorders. As observed in patients, the mean UII level in plasma is higher in SAH patients with VS than in those without VS. Our hypothesis is that the presence of this peptide in plasma may act directly on cerebral vascular cell walls expressing the UT receptor. We show here that the UT receptor is mainly expressed in brain vessels of SAH mice at D7, according to previous description of UT receptor expression at the endothelial and vascular levels in humans, mice, and rats. ${ }^{13,31}$ Our data show a localized expression of UII in cerebral arteries mainly during SAH, suggesting that UII may be expressed by lesioned circle of Willis arteries, leading to activation of UT receptors expressed by vascular components. Here, the evaluation of VS showed a narrowing of the ACA and MCA 7 days post-SAH. In SAH mice receiving urantide, VS appeared to be markedly reduced, suggesting that neurological impairment, associated with long-lasting vascular defects, is at least in part mediated by UII.

The pathophysiological mechanisms responsible for VS after SAH likely involve intracranial cerebral pressure, nitric oxide, oxidative stress, and/or apoptosis of vascular components, but also neuroinflammation. ${ }^{9}$ We and others previously demonstrated that UT receptor couplings to $\mathrm{Gq} / \mathrm{Gi} / \mathrm{o} / \mathrm{G} 13$ proteins allow activation of key signaling cascades, including polyphosphoinositide metabolism, $\mathrm{Ca}^{2+}$, cAMP, nuclear factor- $\mathrm{KB}$, and ERK1/2 in HEK cells expressing human UT, ${ }^{5}$ and the vasoconstriction capacity of UII at de-endothelialized aortic rings., ${ }^{3,25}$ Taken together, these data suggest that the urotensinergic system plays a direct or indirect triggering role in the occurrence of VS. ${ }^{27}$ In light of the effect shown for urantide in the prevention of post-SAH VS and neurological morbidities, we propose that the UT receptor may constitute a new therapeutic target for the treatment of SAH patients.

Our findings in patients show that the UII level in plasma was significantly higher in those with symptomatic VS than in those without symptomatic VS in the acute phase post-SAH, suggesting that further evaluation of UII as a potential marker for early detection of VS is warranted. The higher level of UII in the plasma of VS patients calls into question the causal link between UII and the occurrence of VS. A possible explanation is that levels of UII in plasma of patients with VS may be globally higher without any variation over time. It is also possible that a higher basal UII level prior to SAH could be a risk factor for VS. Measurements performed on blood samples obtained in healthy volunteers showed no significant difference in the UII level in plasma between these volunteers and SAH patients with and without VS. In our murine preclinical SAH model, we observed that the plasma UII level did not differ between Sham and SAH mice at D1 or D10 postSAH. Taken together, these data indicate that an elevated UII level in plasma is probably not a consequence of the hemorrhage event and may rather be a physiological factor arising in patients - and predictive of VS. Thus, patients with high basal UII levels in plasma could be more at risk for symptomatic VS than those with lower UII levels.

In previous studies, patients with symptomatic VS have tended to have poorer neurological outcomes than those without VS..$^{34,35}$ As SAH is a severe cerebrovascular disease, we chose to put the superior cutoff for favorable outcome at 3 on the mRS as previously suggested..$^{33}$ Thus, in the early phase of SAH, high levels of UII in plasma are significantly associated with VS and worse neurological status, but the difference in neurological examination findings was not observed 6 months after hospitalization, likely due to the low number of patients in this pilot study.

Although our results are encouraging, this study has several limitations. The sample size is too small to draw any solid inference about the association between UII and cerebral VS and does not allow clear conclusions on the reasons for finding elevated UII levels in plasma of SAH patients with VS. At this stage, UII should be investigated in larger future studies as a diagnostic/predictive tool of VS since the difference of UII mean concentrations seems to indicate an association of UII in plasma with VS. However, our data provide new information on UII and its receptor and the pathophysiology of VS and SAH. Our work is a pilot study, and the findings that we report here are preliminary and need to be validated in larger studies; the lack of statistical power could have led us to miss some associations or correlations with secondary phenomena with respect to DCI, patient outcome, fatigue, or cognitive deficits. Many confounding and indirect previous observations in both animals and human patients currently support our findings, and the results of this study, albeit in a small cohort, highlight the role of UII in the pathophysiology of SAH and VS.

\section{Conclusions}

We have documented a preventive effect of UT receptor antagonism with urantide, on VS and long-term sensorimotor deficits in a preclinical model. Our prospective clinical study, although inherently limited by sample size, provides the first available evaluation of UII in plasma of SAH patients. A new clinical trial with a larger patient cohort is needed to clarify the role of plasma UII level as a possible diagnostic or prognostic marker for VS prediction, which would also allow the implementation of a new treatment targeting the urotensinergic system. 


\section{Acknowledgments}

We thank the PRIMACEN platform (Normandie Rouen University, France) for imaging equipment and Mr. Arnaud Arabo and Mrs. Huguette Lemonnier (INSERM, DC2N, Mont-SaintAignan, France) for research animal housing.

\section{References}

1. Al Kindi H, Hafiane A, You Z, Albanese I, Pilote L, Genest J, et al: Circulating levels of the vasoactive peptide urotensin II in patients with acute coronary syndrome and stable coronary artery disease. Peptides 55:151-157, 2014

2. Al-Khindi T, Macdonald RL, Schweizer TA: Cognitive and functional outcome after aneurysmal subarachnoid hemorrhage. Stroke 41:e519-e536, 2010

3. Ames RS, Sarau HM, Chambers JK, Willette RN, Aiyar NV, Romanic AM, et al: Human urotensin-II is a potent vasoconstrictor and agonist for the orphan receptor GPR14. Nature 401:282-286, 1999

4. Bellapart J, Jones L, Bandeshe H, Boots R: Plasma endothelin-1 as screening marker for cerebral vasospasm after subarachnoid hemorrhage. Neurocrit Care 20:77-83, 2014

5. Brulé C, Perzo N, Joubert JE, Sainsily X, Leduc R, Castel $\mathrm{H}$, et al: Biased signaling regulates the pleiotropic effects of the urotensin II receptor to modulate its cellular behaviors. FASEB J 28:5148-5162, 2014

6. Castel H, Diallo M, Chatenet D, Leprince J, Desrues L, Schouft MT, et al: Biochemical and functional characterization of high-affinity urotensin II receptors in rat cortical astrocytes. J Neurochem 99:582-595, 2006

7. Chuquet J, Lecrux C, Chatenet D, Leprince J, Chazalviel L, Roussel S, et al: Effects of urotensin-II on cerebral blood flow and ischemia in anesthetized rats. Exp Neurol 210:577584, 2008

8. Cirillo P, De Rosa S, Pacileo M, Gargiulo A, Angri V, Fiorentino I, et al: Human urotensin II induces tissue factor and cellular adhesion molecules expression in human coronary endothelial cells: an emerging role for urotensin II in cardiovascular disease. J Thromb Haemost 6:726-736, 2008

9. Ciurea AV, Palade C, Voinescu D, Nica DA: Subarachnoid hemorrhage and cerebral vasospasm - literature review. J Med Life 6:120-125, 2013

10. Connolly ES Jr, Rabinstein AA, Carhuapoma JR, Derdeyn CP, Dion J, Higashida RT, et al: Guidelines for the management of aneurysmal subarachnoid hemorrhage: a guideline for healthcare professionals from the American Heart Association/American Stroke Association. Stroke 43:1711-1737, 2012

11. Dehdashti AR, Mermillod B, Rufenacht DA, Reverdin A, de Tribolet N: Does treatment modality of intracranial ruptured aneurysms influence the incidence of cerebral vasospasm and clinical outcome? Cerebrovasc Dis 17:53-60, 2004

12. El Amki M, Dubois M, Lefevre-Scelles A, Magne N, Roussel M, Clavier T, et al: Long-lasting cerebral vasospasm, microthrombosis, apoptosis and paravascular alterations associated with neurological deficits in a mouse model of subarachnoid hemorrhage. Mol Neurobiol 55:2763-2779, 2018

13. ElSharkawy RM, Moiety FMS, Hegab HM: Study of urotensin II gene and serum levels in relation to pre-eclampsia. Clin Exp Obstet Gynecol 41:394-398, 2014

14. Feigin VL, Forouzanfar MH, Krishnamurthi R, Mensah GA, Connor M, Bennett DA, et al: Global and regional burden of stroke during 1990-2010: findings from the Global Burden of Disease Study 2010. Lancet 383:245-254, 2014

15. Fung C, De Marchis GM, Katan M, Seiler M, Arnold M, Gralla J, et al: Copeptin as a marker for severity and prognosis of aneurysmal subarachnoid hemorrhage. PLoS One 8:e53191, 2013

16. Germanò A, Caffo M, Angileri FF, Arcadi F, NewcombFernandez J, Caruso G, et al: NMDA receptor antagonist felbamate reduces behavioral deficits and blood-brain barrier permeability changes after experimental subarachnoid hemorrhage in the rat. J Neurotrauma 24:732-744, 2007

17. Jarry M, Diallo M, Lecointre C, Desrues L, Tokay T, Chatenet $\mathrm{D}$, et al: The vasoactive peptides urotensin II and urotensin II-related peptide regulate astrocyte activity through common and distinct mechanisms: involvement in cell proliferation. Biochem J 428:113-124, 2010

18. Johnston SC, Selvin S, Gress DR: The burden, trends, and demographics of mortality from subarachnoid hemorrhage. Neurology 50:1413-1418, 1998

19. Keyrouz SG, Diringer MN: Clinical review: prevention and therapy of vasospasm in subarachnoid hemorrhage. Crit Care 11:220, 2007

20. Lackner P, Dietmann A, Beer R, Fischer M, Broessner G, Helbok R, et al: Cellular microparticles as a marker for cerebral vasospasm in spontaneous subarachnoid hemorrhage. Stroke 41:2353-2357, 2010

21. Lecointre C, Desrues L, Joubert JE, Perzo N, Guichet PO, Le Joncour V, et al: Signaling switch of the urotensin II vasosactive peptide GPCR: prototypic chemotaxic mechanism in glioma. Oncogene 34:5080-5094, 2015

22. Lin CL, Calisaneller T, Ukita N, Dumont AS, Kassell NF, Lee KS: A murine model of subarachnoid hemorrhage-induced cerebral vasospasm. J Neurosci Methods 123:89-97, 2003

23. Macdonald RL, Higashida RT, Keller E, Mayer SA, Molyneux A, Raabe A, et al: Clazosentan, an endothelin receptor antagonist, in patients with aneurysmal subarachnoid haemorrhage undergoing surgical clipping: a randomised, doubleblind, placebo-controlled phase 3 trial (CONSCIOUS-2). Lancet Neurol 10:618-625, 2011

24. Park SL, Lee BK, Kim YA, Lee BH, Jung YS: Inhibitory effect of an urotensin II receptor antagonist on proinflammatory activation induced by urotensin II in human vascular endothelial cells. Biomol Ther (Seoul) 21:277-283, 2013

25. Patacchini R, Santicioli P, Giuliani S, Grieco P, Novellino E, Rovero P, et al: Urantide: an ultrapotent urotensin II antagonist peptide in the rat aorta. Br J Pharmacol 140:1155-1158, 2003

26. Pluta RM, Hansen-Schwartz J, Dreier J, Vajkoczy P, Macdonald RL, Nishizawa S, et al: Cerebral vasospasm following subarachnoid hemorrhage: time for a new world of thought. Neurol Res 31:151-158, 2009

27. Porras-González C, Ureña J, Egea-Guerrero JJ, Gordillo-Escobar E, Murillo-Cabezas F, González-Montelongo M del C, et al: Contractile responses to rat urotensin II in resting and depolarized basilar arteries. J Physiol Biochem 70:193-199, 2014

28. Rabinstein AA, Friedman JA, Nichols DA, Pichelmann MA, McClelland RL, Manno EM, et al: Predictors of outcome after endovascular treatment of cerebral vasospasm. AJNR Am J Neuroradiol 25:1778-1782, 2004

29. Ronne-Engström E, Enblad P, Lundström E: Health-related quality of life at median 12 months after aneurysmal subarachnoid hemorrhage, measured with EuroQoL-5D. Acta Neurochir (Wien) 155:587-593, 2013

30. Schebesch KM, Brawanski A, Bele S, Schödel P, Herbst A, Bründl E, et al: Neuropeptide Y - an early biomarker for cerebral vasospasm after aneurysmal subarachnoid hemorrhage. Neurol Res 35:1038-1043, 2013

31. Sugo T, Murakami Y, Shimomura Y, Harada M, Abe M, Ishibashi Y, et al: Identification of urotensin II-related peptide as the urotensin II-immunoreactive molecule in the rat brain. Biochem Biophys Res Commun 310:860-868, 2003

32. Takata K, Sheng H, Borel CO, Laskowitz DT, Warner DS, Lombard FW: Long-term cognitive dysfunction following experimental subarachnoid hemorrhage: new perspectives. Exp Neurol 213:336-344, 2008 
33. Uyttenboogaart M, Luijckx GJ, Vroomen PC, Stewart RE, De Keyser J: Measuring disability in stroke: relationship between the modified Rankin scale and the Barthel index. J Neurol 254:1113-1117, 2007

34. Vergouwen MDI, Vermeulen M, van Gijn J, Rinkel GJE, Wijdicks EF, Muizelaar JP, et al: Definition of delayed cerebral ischemia after aneurysmal subarachnoid hemorrhage as an outcome event in clinical trials and observational studies: proposal of a multidisciplinary research group. Stroke 41:2391-2395, 2010

35. Zhao B, Yang H, Zheng K, Li Z, Xiong Y, Tan X, et al: Preoperative and postoperative predictors of long-term outcome after endovascular treatment of poor-grade aneurysmal subarachnoid hemorrhage. J Neurosurg 126:1764-1771, 2017

\section{Disclosures}

This work was supported by the OSEO program (grant no. A1006002P/10B0180205), Seinari Normandy maturation program (grant no. HEMORAG-UII/12B01806FM), Fondation pour la recherche sur les AVC (FRM), Normandie Rouen University, INSERM, and Rouen University Hospital. The funding sources had no role in the design and conduct of the study; collection, management, analysis, or interpretation of the data; preparation, review, or approval of the manuscript; and decision to submit the manuscript for publication.

\section{Author Contributions}

Conception and design: Castel, Gastaldi, Gérardin, Proust, Compère. Acquisition of data: Clavier, Mutel, Desrues, Lefevre-Scelle,
Gastaldi, El Amki, Dubois, Melot, Wurtz, Curey, Proust. Analysis and interpretation of data: Castel, Clavier, Desrues, Gastaldi, El Amki, Dubois, Melot, Curey, Compère. Drafting the article: Castel, Clavier, Dubois, Compère. Critically revising the article: Castel, Clavier, Gérardin, Compère. Reviewed submitted version of manuscript: Castel. Approved the final version of the manuscript on behalf of all authors: Castel. Statistical analysis: Clavier, Dubois, Compère. Administrative/technical/material support: Castel, Desrues. Study supervision: Castel, Proust, Compère.

\section{Supplemental Information}

\section{Online-Only Content}

Supplemental material is available with the online version of the article.

Supplementary Information. https://thejns.org/doi/suppl/10. 3171/2018.4.JNS172313.

\section{Previous Presentations}

Preliminary portions of this work were presented in poster form at the annual congress of the French Society of Anesthesiology in September 2014, Paris, France.

\section{Correspondence}

Hélène Castel: Normandie Université, Mont-Saint-Aignan, France. helene.castel@univ-rouen.fr. 